\title{
A plot-scale study of firn stratigraphy at Lomonosovfonna, Svalbard, using ice cores, borehole video and GPR surveys in 2012-14
}

\author{
SERGEY MARCHENKO, ${ }^{1,2}$ VEIJO A. POHJOLA, ${ }^{1}$ RICKARD PETTERSSON, ${ }^{1}$ \\ WARD J. J. VAN PELT, ${ }^{1}$ CARMEN P. VEGA, ${ }^{1}$ HORST MACHGUTH, ${ }^{3}$ \\ CARL E. BØGGILD, ${ }^{4}$ ELISABETH ISAKSSON ${ }^{5}$ \\ ${ }^{1}$ Department of Earth Sciences, Uppsala University, Uppsala, Sweden \\ ${ }^{2}$ Department of Geophysics, The University Centre in Svalbard, Longyearbyen, Norway \\ ${ }^{3}$ Department of Geography, University of Zürich, Zürich, Switzerland \\ ${ }^{4}$ Centre for Arctic Technology, Technical University of Denmark, Copenhagen, Denmark \\ ${ }^{5}$ Norwegian Polar Institute, Tromsø, Norway \\ Correspondence: Sergey Marchenko <sergey.marchenko@geo.uu.se>
}

\begin{abstract}
Spatial heterogeneity of snow and firn properties on glaciers introduces uncertainty in interpretation of point and profile observations and complicates modelling of meltwater percolation and runoff. Here we present a study of the temporal and spatial dynamics of firn density and stratigraphy at the plot-scale $(\approx 10 \mathrm{~m} \times 10 \mathrm{~m} \times 10 \mathrm{~m})$ repeated annually during 2012-14 at the Lomonosovfonna icefield, Svalbard. Results from cores, video inspections in boreholes and radar grid surveys are compared. Ice layers $0.1-50 \mathrm{~cm}$ thick comprised $\approx 8 \%$ of the borehole length. Most of them are $1-3 \mathrm{~cm}$ thick and could not be traced between boreholes separated by $3 \mathrm{~m}$. Large lateral variability of firn structure affects representativeness of observations in single holes and calls for repeated studies in multiple points to derive a representative stratigraphy signal. Radar reflections are poorly correlated with ice layers in individual boreholes. However, the match between the high amplitude peaks in the grid-averaged radar signal and horizons of preferential ice layer formation revealed by averaging the video surveys over multiple boreholes is higher. These horizons are interpreted as buried firn layers previously exposed to meltfreeze or wind-driven densification and several of them are consistently recovered throughout three field campaigns.
\end{abstract}

Keywords: borehole video, firn core, radar, stratigraphy

\section{INTRODUCTION}

The ongoing Arctic warming results in elevated rates of meltwater production on glaciers and ice sheets (Vaughan and others, 2013). However, the amount of melt is not necessarily equal to the loss of water from a glacial system, as runoff from accumulation zones of glaciers is reduced by refreezing of meltwater in the snow and firn pore space (e.g. Reijmer and others, 2012) or retention in perennial firn aquifers (Forster and others, 2014; Christianson and others, 2015). Accumulation zones hence act as reservoirs of meltwater in frozen and/or liquid form, effectively reducing and delaying runoff (e.g. Harper and others, 2012). Accurate description of subsurface processes in snow and firn is important to reduce uncertainties in measurements and simulations of the glacier mass and energy balance.

Snow and firn physical properties are known to exhibit strong lateral variability (e.g. Bell and others, 2008; Schweizer and others, 2008). At the scale of metres the original heterogeneity of a snowpack is created by the irregular pattern of snow deposition influenced by the local topography and the wind field (Sturm and Benson, 2004). Conditions in snow and firn below the surface continuously evolve, which results in rapid and spatially non-uniform thermal and mechanical changes (Colbeck, 1982). A major contribution to the local spatial variations in structure of snow and firn comes from the flow and refreezing of water (Jordan and others, 2008).

While uncertainties in interpretation and extrapolation of point and profile observations (Machguth and others, 2006; Bell and others, 2008; Trujillo and Lehning, 2015) can be better assessed and reduced by observation of the lateral heterogeneity of snow and firn properties, it is a major challenge to select a reliable field technique. In relatively thin snow and firn packs visual description of pit walls and direct density measurements are conventionally used (Benson, 1960; Sturm and Benson, 2004; Fierz and others, 2009; Sugiyama and others, 2012). Alternatively, near infrared imagery (Tape and others, 2010) or a penetrometer, measuring resistance of snow to insertion of a rod (Schneebeli and others, 1999; Proksch and others, 2015), can be used for detailed two-dimensional descriptions of the snow properties.

Coring can be used for stratigraphical studies in deeper snow and firn (Brown and others, 2011; Harper and others, 2012; Machguth and others, 2016). Video observations in boreholes (e.g. Pohjola, 1994; Malone and others, 2013) provide a less detailed but also less logistically demanding alternative to coring for description of firn stratigraphy (Langhammer, 2014), location of summer/autumn erosion surfaces (Hubbard and others, 2008) and measurement of firn compaction rate (Hawley and Waddington, 2011). 
Ground penetrating radar (GPR) measures the variability of dielectric permittivity and electrical conductivity of a medium in space, which serve as a proxy for its physical characteristics (Arcone, 2009). It offers a relatively affordable and fast alternative to studies in pits and boreholes. GPR is a non-invasive method, which is of particular importance in snow and firn studies as it allows for repeated surveys. However, interpretation of results and validation is often challenging (e.g. Brown and others, 2011). Frequency modulated continuous wave radars having high vertical resolution (Marshall and others, 2007) allow to detect seasonal subsurface layers (Richardson and others, 1997) and accumulation rates (Forster and others, 1991) and may be used to sense flow fingers in a thin seasonal snowpack (Albert and others, 1999). Pulse radar systems are usually operated at lower central frequencies and can reveal the structure of deeper snow and firn packs. Gridded and profile GPR surveys combined with coring have been used to study layering in firn on the western slope of the Greenland ice sheet (Dunse and others, 2008; Brown and others, 2011), at Kongsvegen, Svalbard (Langley and others, 2009) and in the Canadian Arctic (Gascon and others, 2013).

Given the aforementioned limitations in the spatial and temporal extent and resolution of field studies, the need to assess the impact of meltwater flow and retention in snow and firn on glacier mass and energy balance at the scale of glaciers, ice caps or even ice sheets resulted in a number of modelling approaches. Layered models describing water flow through snow and firn (e.g. Bartelt and Lehning, 2002; Reijmer and Hock, 2008; Gascon and others, 2014) often utilize the concept of a horizontal wetting front: water advances when the refreezing capacity of the current layer is eliminated and capillary forces cannot accommodate additional water supply. However, both field (e.g. Schneebeli, 1995; Bøggild, 2000; Campbell and others, 2006) and laboratory (e.g. Waldner and others, 2004; Katsushima and others, 2013) observations show that water percolating through snow and firn pack often follows preferential flow paths originating at stratigraphic boundaries and infiltration along them is more effective than in the adjacent snow and firn volumes. The limited success in multidimensional simulation of water flow in snow (e.g. Illangasekare and others, 1990; Katsushima and others, 2009; Leroux and Pomeroy, 2016) and, particularly, thicker firn packs is partly explained by the lack of empirical data on the snow and firn physical properties and their spatial variability.

The purpose of this paper is to present results from a 3 year plot scale $(\approx 10 \mathrm{~m} \times 10 \mathrm{~m} \times 10 \mathrm{~m})$ firn stratigraphy study done at Lomonosovfonna (1200 m a.s.l.), Svalbard, using cores, borehole video and GPR surveys and to report on the strengths, weaknesses and agreement of results from the different methods.

\section{STUDY SITE}

Lomonosovfonna is a large ice field on central Spitsbergen, Svalbard, nourishing several outlet glaciers including Nordenskiöldbreen (Fig. 1a). Surface energy and mass balance along with firn conditions were studied by Zinger and others (1966), Zagorodnov and Zotikov (1980), Pälli and others (2002), Van Pelt and others (2012, 2014). Deep ice cores were drilled at Lomonosovfonna in 1997 (Isaksson and others, 2001) and in 2009 (Wendl, 2014; Vega and others, 2015) and a series of shorter cores was drilled and studied in the recent years (Vega and others, 2016).

The altitude of the equilibrium line at Nordenskiöldbreen was estimated at $719 \mathrm{~m}$ a.s.I. (Van Pelt and others, 2012). The study site is in the accumulation zone at $78.824^{\circ} \mathrm{N}$, $17.432^{\circ} \mathrm{E}, 1200 \mathrm{~m}$ a.s.l. on a gently sloped dome. The local ice thickness derived from a GPR survey is $192 \pm 5.1 \mathrm{~m}$ (R. Pettersson, unpublished data). Ice coring at the same site in 2009 showed a thickness of the firn layer of $\sim 20 \mathrm{~m}$ (Wendl, 2014). In accordance with the long-term warming trends observed in Svalbard (Nordli and others, 2014) and Lomonosovfonna (Van de Wal and others, 2002), during 1989-2010 the mean annual air temperature at Nordenskiöldbreen increased by more than $1^{\circ} \mathrm{C}$, resulting in a negative glacier-averaged mass balance of $-0.39 \mathrm{~m}$ w.e. $a^{-1}$ (Van Pelt and others, 2012). Recent field and
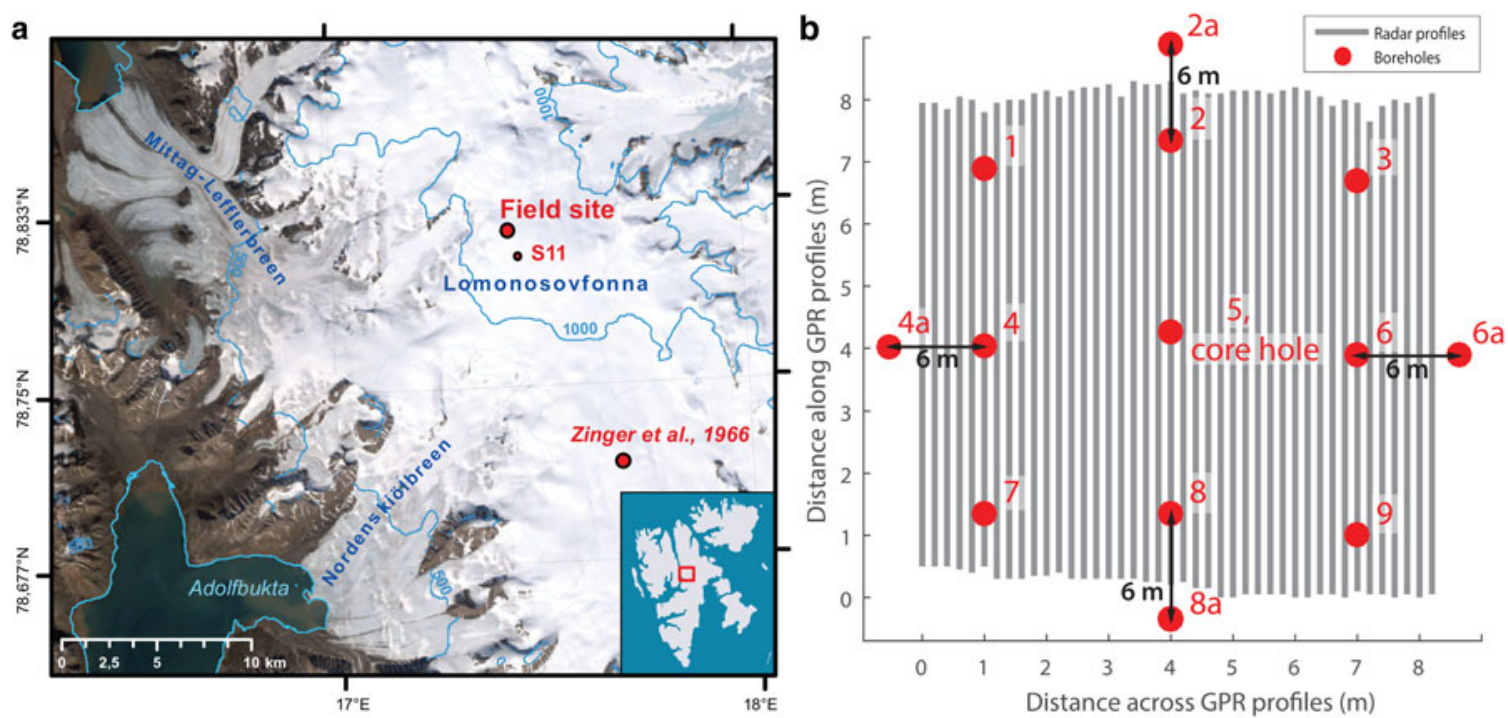

Fig. 1. (a) location of the study site at the Lomonosovfonna ice field with a map of Svalbard shown in the lower right corner. Also shown is the location of the Soviet expedition in 1965 Zinger1966; (b) the grid of boreholes and GPR profiles used in the study site. Note: the distances between boreholes 2 and $2 a, 4$ and $4 a, 6$ and $6 a, 8$ and $8 a$ are not to the main scale. 
modelling results in the area showed that at the elevation of the study site the average accumulation rate during 2007-12 is $\approx 0.75 \mathrm{~m}$ w.e. $\mathrm{a}^{-1}$ (Van Pelt and others, 2014) and the melt rate during 1989-2010 was on average $\approx 0.34 \mathrm{~m}$ w.e. $\mathrm{a}^{-1}$ (Van Pelt and others, 2012). Despite percolation of water below $10 \mathrm{~m}$, runoff is small as most meltwater refreezes in the snow and firn profile exerting a major influence on density, temperature and metamorphism in firn at the field site (Van Pelt and others, 2012).

\section{METHODS}

For presentation of some of the results the glacier surface in April 2014 was defined as the common reference with respect to depth for all 3 years. The vertical offsets of the glacier surfaces in April 2012 and 2013 from that common reference resulting from accumulation are defined as 2.44 and $1.32 \mathrm{~m}$, respectively, based on annual measurements at the nearby stake S11 (Fig. 1a) in April 2012-14. This aligns layers deposited at approximately the same time but recovered in different field campaigns. However, the effect of gravitational densification is not accounted for and additional vertical shifts caused by local-scale lateral variability in accumulation rate are possible. Moreover, we follow the definition of firn as the snow that has survived one or more ablation seasons but has not been transformed to ice (Cogley and others, 2011).

\subsection{Firn cores}

Firn cores were collected each year using a Kovacs corer with the internal diameter of $10.5 \mathrm{~cm}$. They were used for direct observation of stratigraphy and density. Coring locations in 2012-14 were within $50 \mathrm{~m}$ from each other. The length of the retrieved cores was $9.9 \mathrm{~m} \mathrm{(2012),} 11.3 \mathrm{~m}$ (2013) and $13.6 \mathrm{~m}$ in 2014 (Table 1). The bottom depth of each core section was calculated as the summed lengths of extension rods below the surface plus the length of the coring barrel before extraction to the surface. Coring below $\approx 10 \mathrm{~m}$ was challenging in all three field campaigns as the cold barrel tended to freeze on to the temperate firn at this depth. During extraction and handling of the firn cores 4$7 \%$ of the core record was lost in different years.

The firn cores were processed in the cold laboratories of the University Centre in Svalbard (Longyearbyen) and of the Norwegian Polar Institute (Tromsø). To enable comparison of firn cores with video observations and GPR measurements the number of distinguished facies was limited to two: porous icy media (snow and firn) and solid ice. Ice lenses

Table 1. Details on stratigraphy data collected using firn cores, video and GPR surveys

\begin{tabular}{llccc}
\hline & \multicolumn{1}{c}{ Parameters } & 2012 & 2013 & 2014 \\
\hline Core & Depth of core $(\mathrm{m})$ & 9.93 & 11.34 & 13.64 \\
Video & Number of surveyed boreholes & 13 & 5 & 4 \\
& Mean depth $(\mathrm{m})$ & 9.56 & 9.32 & 11.30 \\
& Distance to the core hole $(\mathrm{m})$ & 0.3 & ca 50 & ca 50 \\
GPR & Number of surveyed profiles & 42 & 46 & 31 \\
& Mean length of profiles (m) & 7.9 & 9.0 & 6.2 \\
& Depth of survey (m) & 10.7 & 4.7 & 10.6 \\
& Distance to the core hole $(\mathrm{m})$ & 0 & ca 10 & ca 50 \\
\hline
\end{tabular}

thicker than $1 \mathrm{~mm}$ were noted. The density of the firn column was derived by measuring the mass and dimensions of core samples. Core pieces with uneven geometry were cut in rectangular samples to reduce uncertainty in calculation of their volume. In 2012 and 2014 density was measured in $\approx 0.1 \mathrm{~m}$ long samples, while in 2013 bulk density of core pieces up to $0.5 \mathrm{~m}$ long was measured.

\subsection{Borehole video surveys}

Optical properties of firn were inspected using a video camera with an internal light source in multiple boreholes with a diameter of $5.5 \mathrm{~cm}$ drilled by a Kovacs auger. Brushing the boreholes to remove the drill chips from the walls greatly improved the quality of the video surveys, but at the same time the loose material accumulated at the bottom of the narrow hole and reduced the depth of survey.

The principle behind deriving stratigraphy data from borehole videos is that ice, being less reflective to light than snow and firn, appears darker in the video frames (e.g. Sjögren and others, 2007; Langhammer, 2014). Two types of media were distinguished in the videos: firn and ice.

Boreholes surveyed in 2012-14 were positioned on a grid (Fig. 1b): nine holes (labelled 1-9) were placed on a square grid with $3 \mathrm{~m}$ spacing, four other holes (labelled 2a, $4 a$, $6 a$ and $8 a$ ) were located $6 \mathrm{~m}$ away from the four sides of the grid. In 2012 we filmed all 13 holes during lowering and lifting of the camera, in 2013 five holes (labelled 2-6) and in 2014 four holes (labelled 6-9) within similar grids were drilled and surveyed (Table 1). In 2012 hole 5 was drilled in $0.3 \mathrm{~m}$ from the cored borehole and thus the video data grid is centred on it (Fig. 1b). In 2013 and 2014 the video data grids were within $100 \mathrm{~m}$ from the coring locations.

Depth marks appearing in video frames were generated by a rotary encoder coaxial with the wheel feeding the camera cable into the borehole. The accuracy of assessing the absolute depth with respect to the surface is estimated to be better than $0.1 \mathrm{~m}$ based on the difference between initial and final depth values (i.e. before lowering and after rising of the camera). The resulting videos with the resolution of $720 \times$ 576 pixels were visually analysed and the upper and lower depths of ice layers were recorded with the precision of 5 $\mathrm{mm}$ as they appeared in the boreholes.

Multiple stratigraphy profiles derived in each of the three field campaigns in April 2012-14 allowed to derive three laterally averaged datasets revealing the horizontally consistent patterns in firn stratigraphy. For each year the probability of ice layer occurrence for $5 \mathrm{~mm}$ depth intervals was defined as the ratio between the number of video surveys that indicated an ice layer there and the number of surveys that reached that particular depth.

\subsection{GPR surveys}

Grids of GPR profiles were measured using Malå GeoScience ProEx impulse radar and shielded antennas with the central frequency of $800 \mathrm{MHz}$. In 2012 the GPR grid intersected with the grid of holes surveyed by camera (Fig. 1b), while in other years centres of the radar grids were positioned in 10-50 $\mathrm{m}$ from the centres of the boreholes grids (Table 1). At such distances there are no significant variations in the surface conditions, and the general character of the stratigraphy can be expected to be preserved while the horizontal extent of most ice layers in snow and firn is typically smaller 
and these details are likely to be lost. The radar was triggered every $0.05 \mathrm{~m}$ along the profiles by a distance wheel encoder and a stack of four traces consisting of 2024 samples was measured. Spacing of $0.2 \mathrm{~m}$ between profiles was controlled by wooden markers plugged in snow at the sides of the grid and a string connecting them. Several tens of radar profiles 6$9 \mathrm{~m}$ long each were measured in 2012-14 field campaigns (Table 1). To facilitate the comparison of the GPR data against the video surveys done in 2012, the GPR traces coinciding with the inspected boreholes were marked in the field.

GPR data were processed using custom functions written in MATLAB programming language. First a dewow filter was applied, then the zero time of every trace was adjusted to the first sample exceeding $5 \%$ of the trace amplitude range (Yelf, 2004). Gain correction was applied to account for the loss of the radar wave power with depth. Finally, a low-pass filter eliminated the frequencies higher than 1000 $\mathrm{MHz}$ from the dataset.

For analysis of the spatial heterogeneity of firn properties we attempt to derive a 3-D GPR dataset. To do so, we first aligned the GPR profiles in the along-profile direction adopting the approach originally suggested by Evangelidis and Psarakis (2008) for alignment of images to radargrams of neighbouring profiles. Then Whittaker-Shannon interpolation was applied to reduce the separation between profiles to $0.05 \mathrm{~m}$ preserving the frequency characteristics of the original signal (Oppenheim and others, 1999). This multiplied the number of profiles by ca 4. Finally, 3-D Kirchhoff time domain migration (e.g. Hagedoorn, 1954; Schneider, 1978) using an anti-aliasing filter (Gray, 1992) was applied to relocate the reflection events to their original position. We then applied automatic gain correction with the window size of 180 samples $(\approx 9 \%$ of the total number of samples in a trace) in order to keep amplitude of both noise and signal at the same level throughout the profile.

For the conversion of the vertical scale from two-way travel time to depth the Kovacs and others (1995) relation was used. The density values measured in the firn cores were averaged over $0.5 \mathrm{~m}$ intervals and converted to relative real dielectric constants giving the interval velocity of the GPR signal. While in 2012 and 2014 the chosen sampling frequency allowed sounding to a depth of $\approx 10.6 \mathrm{~m}$ with $\approx 5 \mathrm{~mm}$ spacing between samples, in 2013 the sampling frequency was doubled resulting in equivalent reduction of the depth of sounding and sample spacing. With the mean velocity of the GPR signal of $0.2 \mathrm{~m} \mathrm{~ns}^{-1}$ and the central frequency of $800 \mathrm{MHz}$ the theoretical wavelength $\lambda$ is $0.25 \mathrm{~m}$ and, consequently, our setup is able to distinguish only between reflectors separated by more than $\lambda / 2=0.125 \mathrm{~m}$ (Hubbard and Glasser, 2005).

A composite GPR signal was calculated to highlight horizontally persistent horizons with increased backscatter for each of the three datasets. For that the sum of the instantaneous amplitudes of several thousand individual traces was calculated using the Hilbert transform (Oppenheim and others, 1999) and scaled to have the maximum at 0.5 to facilitate the visual comparison with the data from video inspections.

To facilitate the quantitative analysis of the GPR data and make it comparable with the stratigraphical descriptions in boreholes we use a thresholding technique to derive reflectors in the radar traces in a consistent way compared with subjective visual interpretation of radargrams. First instantaneous amplitudes of all radar traces were calculated, then the samples for which the parameter is larger than the mean plus 2 standard deviations (SDs) of all instantaneous amplitudes were defined as reflecting while others are classified as non-reflecting (Fig. 2). In the example shown in Figure 2 four reflectors (marked by grey bars) were retrieved from the trace, while the rest of the column was assigned to be non-reflecting. The routine effectively cuts off $5 \%$ brightest samples on Hilbert filtered radargrams. The choice of the threshold is arbitrary and larger values result in smaller fractions of samples identified as reflecting, consequently, reflectors are fewer and thinner. It has to be noted, though, that the thickness of reflectors rather depends on the strength of the dielectric permittivity and electrical conductivity contrasts between firn layers than on the actual thickness of the layers at the interface with which the backscatter event is initiated.

\subsection{Firn temperature measurements}

During the periods April-October 2012, April-July 2013 and April 2014-April 2015 the evolution of firn temperature was monitored in shallow boreholes using thermistor strings. To minimize preferential percolation of water along them, the

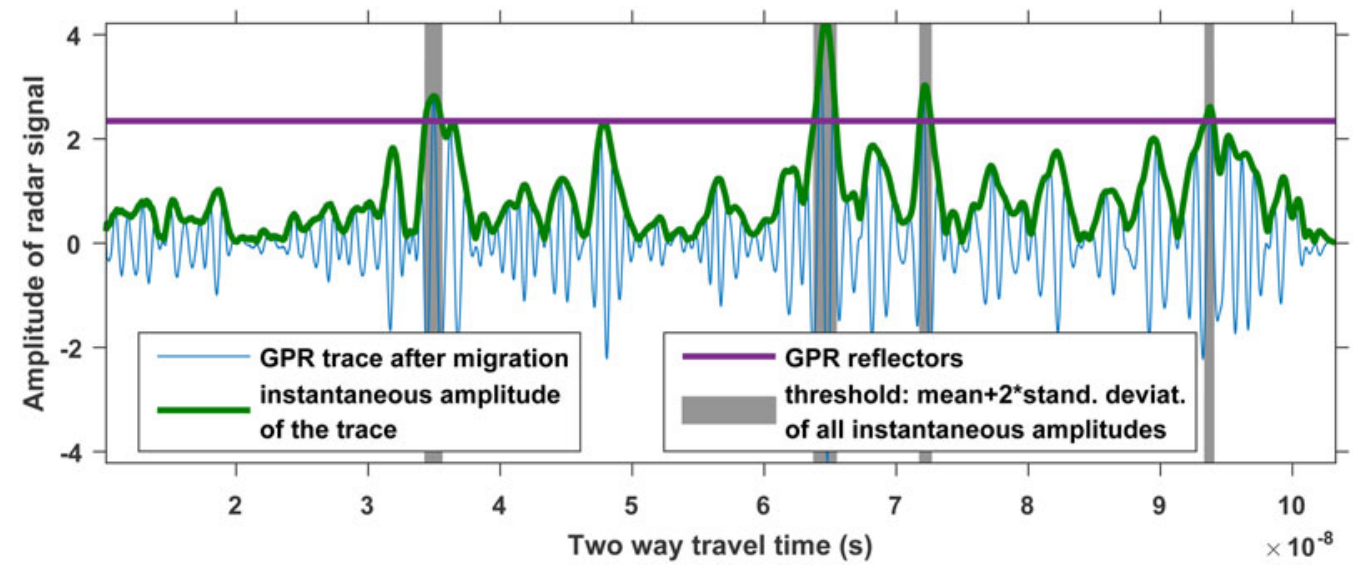

Fig. 2. Analysis of GPR data. The blue curve is a radar trace from processed and migrated dataset. The green curve shows the corresponding instantaneous amplitudes derived using the Hilbert filter. Similar series were used in Figures 5-7. The violet line shows the threshold defined as the mean plus two standard deviations of all instantaneous amplitudes in traces measured in one field campaign. It was used to decipher reflectors in individual radar traces, which are shown as grey-shaded two-way travel time intervals. 
holes were backfilled with surface snow. Voltage drop over temperature stable reference resistors connected in series with thermistors was measured by a Campbell Scientific CR10X logger. Accuracy of temperature measurements is estimated as $<0.2^{\circ} \mathrm{C}$.

\section{RESULTS}

\subsection{Firn temperature and density}

The measured evolution of the snow and firn temperature is illustrated by Figure 3. The extent and strength of the cold wave in the upper metres of the firn profile were similar by 10 May in 2012 and 2013. In 2013 the first liquid water infiltration event occurred on the 3 June, which is 17 days earlier than in 2012. In the next few days a warm wave was observed in the upper part of the profile, but after a week it was reduced by the surface cooling. By the end of August 2012 the firn profile down to $12 \mathrm{~m}$ was temperate. This was likely also the case in the succeeding year as already by mid-July the upper $5 \mathrm{~m}$ of the snow and firn pack reached that state.

Figure $4 \mathrm{~d}$ shows the density distribution measured in the three firn cores. Gravitational densification and freezing of liquid water in the firn matrix can be expected to result in an increase of the firn density between the field campaigns. The most prominent density increase (of $\approx 130 \mathrm{~kg} \mathrm{~m}^{-3}$ ) occurred between April 2013 and April 2014 in the depth range $1.5-5.3 \mathrm{~m}$. The period was also marked by density rise in the lower part of the profile (10-12.7 m) of $\approx 80 \mathrm{~kg} \mathrm{~m}^{-3}$. Other density increases over time reach comparable values

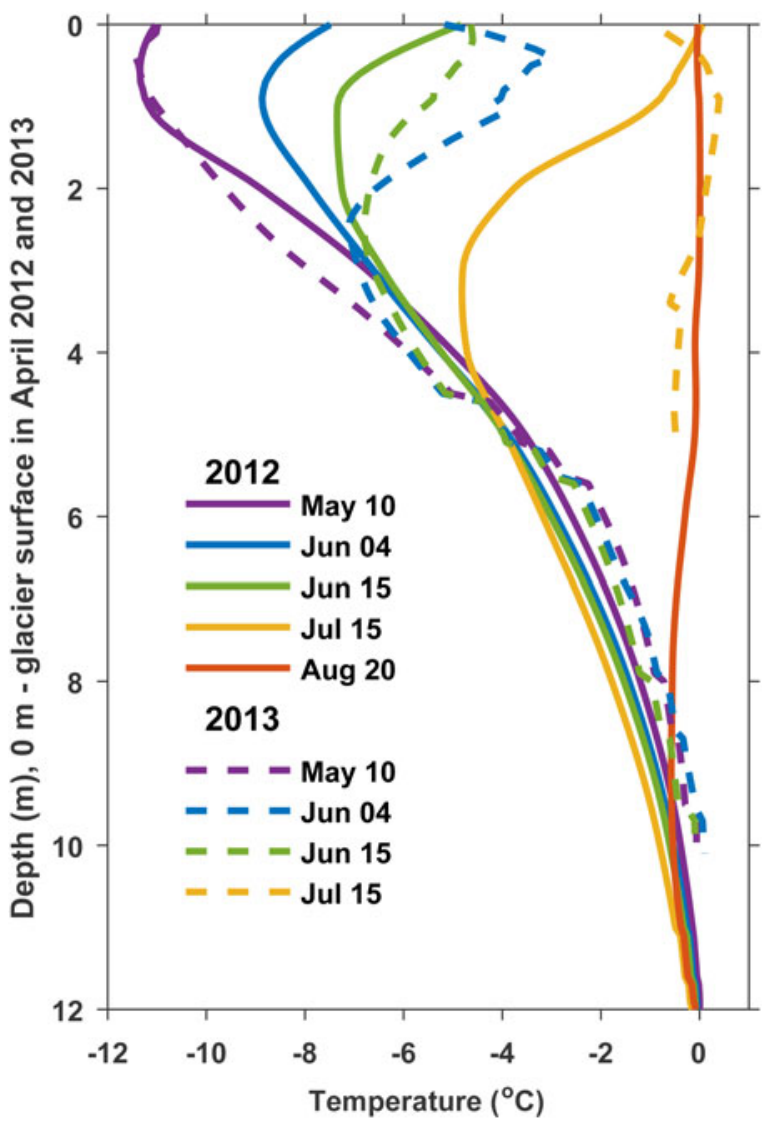

Fig. 3. Snow and firn temperature measured during 2012 and 2013.

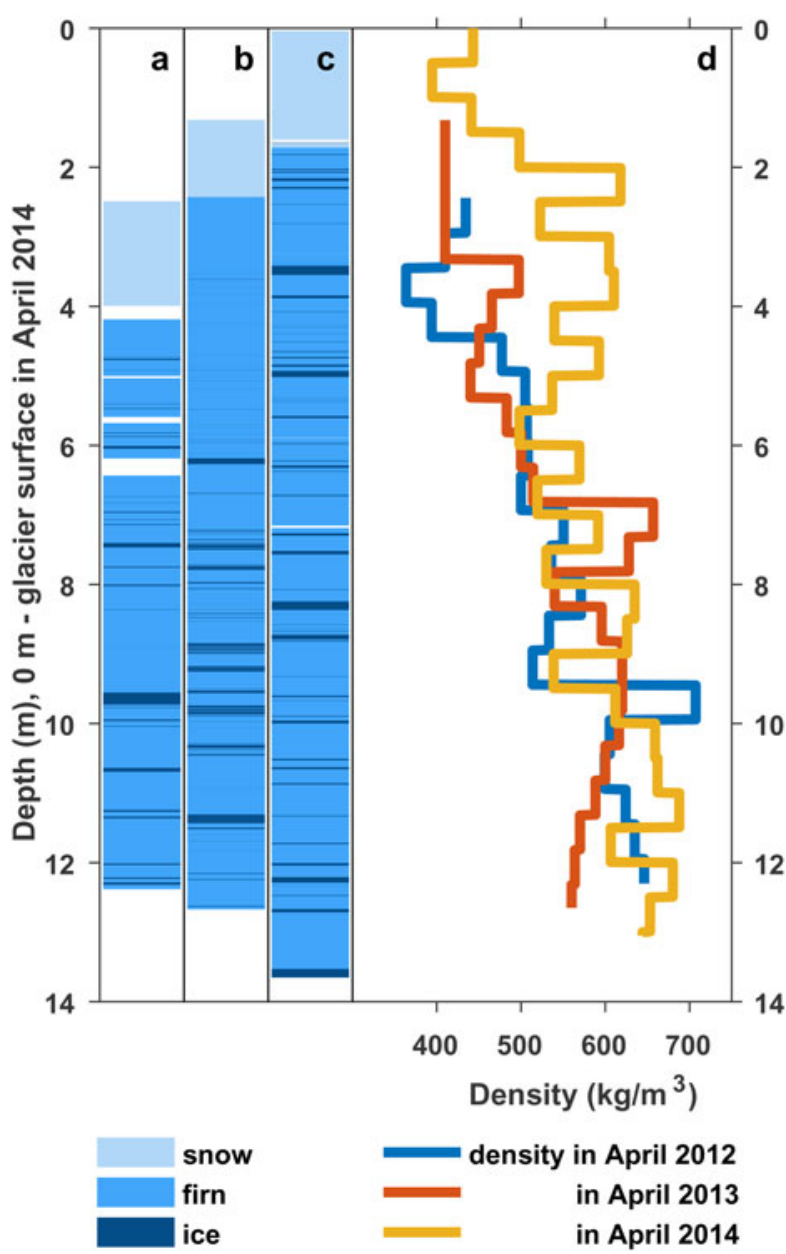

Fig. 4. Stratigraphy distribution observed in firn cores drilled in 2012 (a), 2013 (b) and 2014 (c). Different shades of the blue colour mark the depth intervals where snow (light), firn and ice (dark) were observed. Density distribution measured in cores in 2012-2014 (d).

but have smaller vertical extent (typically $<1 \mathrm{~m}$ ) and, given the local lateral variability in firn conditions, could be a result of cores being drilled at different locations.

\subsection{Firn stratigraphy}

\subsubsection{Firn cores}

The firn core profiles are presented in Figures $4 \mathrm{a}-\mathrm{c}$. The visual observation of the firn cores gives the most detailed picture of the firn stratigraphy and allows to detect even very thin ice layers $(<1 \mathrm{~mm})$ and to distinguish between layers with different shape and size of the snow and firn grains and pores. Details of the firn structure such as laterally inconsistent ice volumes, ice layers with uneven or inclined boundaries, vertical ice columns above ice layers are apparent from the core face. The entire length of the three cores recovered in 2012-14 consists of snow and firn with several dozen of ice layers (Table 2) from $1 \mathrm{~mm}$ to $0.2 \mathrm{~m}$ thick. The average thickness of ice layers observed in cores was $1.4-2.3 \mathrm{~cm}$ for the different years, but the variability is high with a SD larger than the mean value (Table 2). The mean number of ice layers per metre of core is 3.2-5.8 corresponding to the ice content in firn (i.e. mean ice layer thickness multiplied by the number of ice layers per metre of core) of $\approx 6-10 \%$. 
Table 2. Number and thickness of ice layers/reflectors in individual boreholes/GPR traces

\begin{tabular}{|c|c|c|c|c|c|c|c|c|c|c|}
\hline & \multirow[t]{2}{*}{ Parameters } & \multicolumn{3}{|c|}{2012} & \multicolumn{3}{|c|}{2013} & \multicolumn{3}{|c|}{2014} \\
\hline & & $\mathrm{AM}$ & $\mathrm{SD}$ & RSD & AM & SD & RSD & AM & SD & RSD \\
\hline \multirow[t]{2}{*}{ Core } & Number of ice layers per depth unit $\left(\mathrm{m}^{-1}\right)$ & 3.2 & - & - & 5.8 & - & - & 4.3 & - & - \\
\hline & Thickness of ice layers $(\mathrm{cm})$ & 2.0 & 3.2 & 158 & 1.4 & 1.7 & 117 & 2.3 & 3 & 129 \\
\hline \multirow[t]{2}{*}{ Video } & Number of ice layers in per depth unit $\left(\mathrm{m}^{-1}\right)$ & 1.7 & 0.4 & 21 & 1.6 & 0.3 & 20 & 1.5 & 0.6 & 38 \\
\hline & Mean thickness of ice layers $(\mathrm{cm})$ & 4.5 & 1.6 & 37 & 3.7 & 1.2 & 32 & 5.9 & 1.8 & 30 \\
\hline
\end{tabular}

$\mathrm{AM}$, arithmetic mean; SD, standard deviation; RSD, relative SD in \% (SD/AM).

Note on SD in thickness: for cores it is for ice layers recovered in a single firn core while for video surveys it is for the mean thicknesses of ice layers from different boreholes.

\subsubsection{Borehole video surveys}

Interpretation of firn strata from borehole videos brought a less detailed picture of the firn stratigraphy (Fig. 5) than the visual description of the cores: it was only possible to reliably distinguish between two types of facies (firn and ice). In Figure 6 we compare the firn stratigraphy derived in 2012 by video observations in borehole 5 (d) and from the core (c) drilled in $0.3 \mathrm{~m}$ from each other. While some ice layers captured by direct observations are matched within $0.15 \mathrm{~m}$ by ice layers in the video survey (e.g. at 4.9, 7.1-7.3, 7.5, 8.3 and $9.7 \mathrm{~m})$, most and, primarily, the thinner ice layers

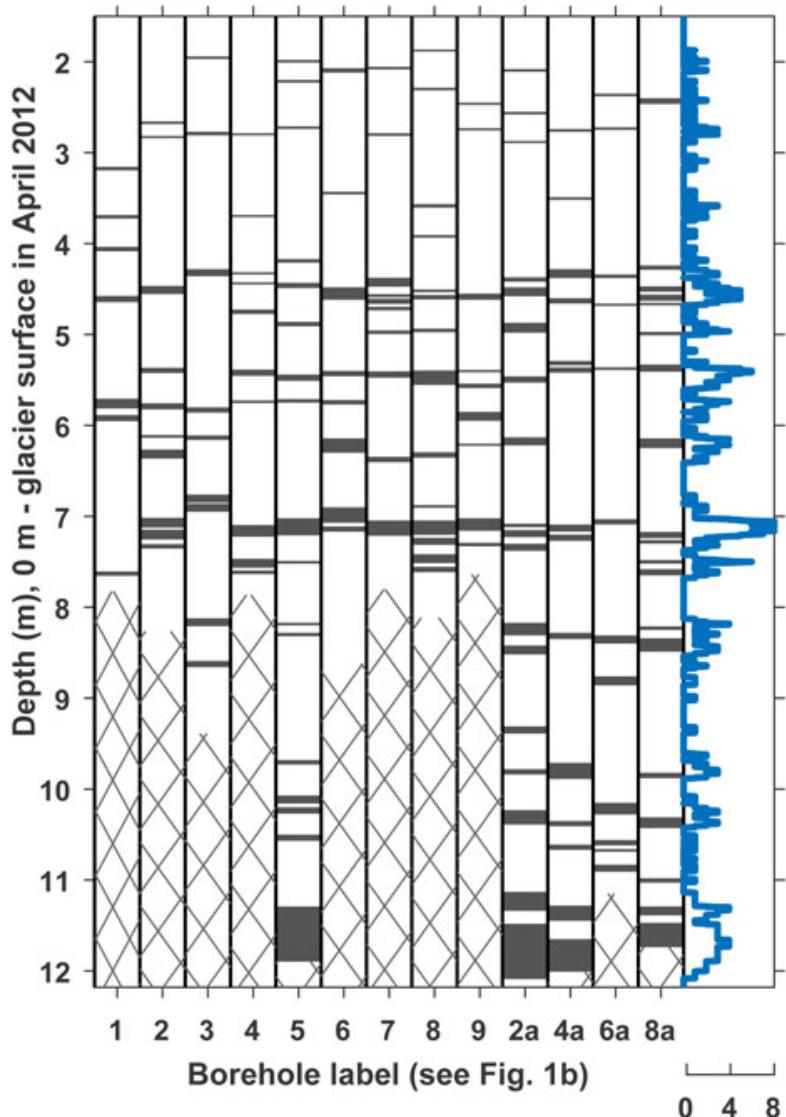

Number of boreholes with an ice layer

Fig. 5. Firn stratigraphy observed in 2012 using video surveys. Ice layers found in different boreholes are shown as horizontal black lines. The blue curve to the right illustrates the number of boreholes that indicated an ice layer at a specific depth. found in core were not seen in borehole 5 . That could be a result of imperfections in data acquisition techniques as well as a consequence of limited lateral extent of the ice layers.

The number of ice layers detected by video surveys in multiple boreholes in the three field campaigns was only $25-50 \%$ of the number found with core observations (Table 2). The average thickness of ice layers is $3.7-5.9 \mathrm{~cm}$,

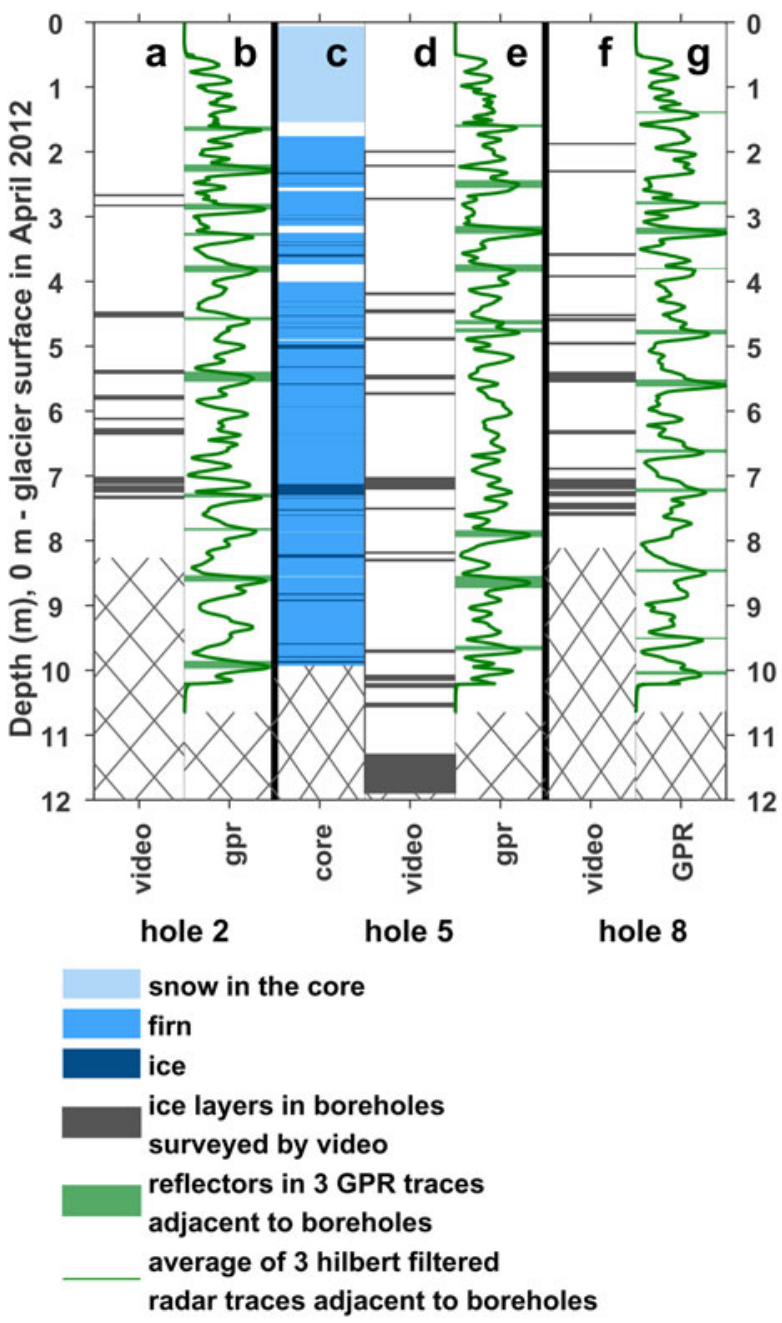

Fig. 6. Vertical profiles of firn stratigraphy derived in 2012 using different methods: firn core stratigraphy (c); ice layers recovered by video surveys in boreholes 2 (a), 5 (d) and $8(\mathrm{f})$; reflectors and average instantaneous amplitude calculated for 3 radar traces sounded above boreholes 2 (b), 5 (e) and 8 (g). 
which is about double the size measured in the firn cores. Thick ice layers are more characteristic for the lower part of the profile (Fig. 5) and in boreholes 5 and 9 at the depth of $12 \mathrm{~m}, 0.5 \mathrm{~m}$ thick ice layers were observed. Ice layers constitute $\approx 6-9 \%$ of the profile (Table 2 ), a value close to the relative ice content of the cores.

Video observations in multiple boreholes show high lateral variability of the ice volumes in firn. As illustrated by Figure 5, only few layers (for example at 4.5, 5.5 and $7.0 \mathrm{~m}$ ) can be consistently tracked among neighbouring boreholes, suggesting that horizontal extent of most ice layers is less than the distance between holes (ranging between 3 and $18 \mathrm{~m}$ ). The high lateral variability of ice layers in firn is further confirmed by the number of boreholes that showed an ice layer at a certain depth (blue curve in Fig. 5), according to which most of the ice layers were observed in less than two boreholes in 2012 and single boreholes in the other 2 years. Furthermore, the SDs in the number and mean thickness of ice layers recovered in the different holes (Table 2) constitute up to $20-40 \%$ of the corresponding mean values, which also suggests the low representativeness of a stratigraphy record derived at a single point.

Lateral averaging of the video data from multiple boreholes surveyed in each year allowed to derive more representative descriptions of the ice layers in firn. Up to eight boreholes showed ice layers within the same $5 \mathrm{~mm}$ depth interval in 2012 (Fig. 5) and a maximum of four holes had ice layers at the same depth in 2013 and 2014. The maxima in the grid averaged video data reach $0.3-1$ and correspond to horizons with high probability of ice layer occurrence. Referenced to the glacier surface in April 2014, in 2012 the horizons were found at the depths of 7.1, 7.8, 8.7, 9.5, 10.7, 12.1, 12.7 and $14.0 \mathrm{~m}$ (Fig. 7a), in 2013 at 3.7, 7.1, 8.8, 9.5, $10.8 \mathrm{~m}$ (Fig. 7b) and in 2014 at 3.2, 6.7, 7.9, 9.0, 10.6, $11.5 \mathrm{~m}$ (Fig. 7c). Some of these depth levels are consistent throughout the 3 years of observations, as will be discussed below. In 2012, when the video inspections were done in the largest number of boreholes (13), a positive trend with respect to depth was revealed in the probability values reached at the horizons of preferential ice formation (Fig. 7a), suggesting more laterally consistent and thick layers in the lower part of the profile.

\subsubsection{GPR surveys}

Radargrams of the profiles done in 2012 are presented in Figure 8. Individual radar profiles show regions of increased backscatter that are typically elongated in the horizontal direction (Fig. 8a). However, identification of the preferential reflecting horizons over longer distances $(\approx 0.5 \mathrm{~m})$ is ambiguous due to the limited lateral extent of individual high backscatter regions. The latter particularly applies to the lower part of the profile (below $5 \mathrm{~m}$ ) where the vertical gradients in backscatter intensity are lower. The latter observation is also confirmed by the averaged radar traces for each of the years (green curves in Fig. 7) having steeper gradients in the upper part of the profile than in the lower. Reflecting horizons become more apparent after calculating the average of more than 100 profiles in the 3-D GPR datasets in the across-profile direction. The averaged profile from 2012 (Fig. 8b) exhibits horizontally consistent reflections at several depths: 1.7, 2.3, 3.2, 3.8, 4.7, 5.6, 6.6, 7.3, 8.6 and $10.1 \mathrm{~m}$, which are less intermittent than the areas with increased backscatter found at same levels in the

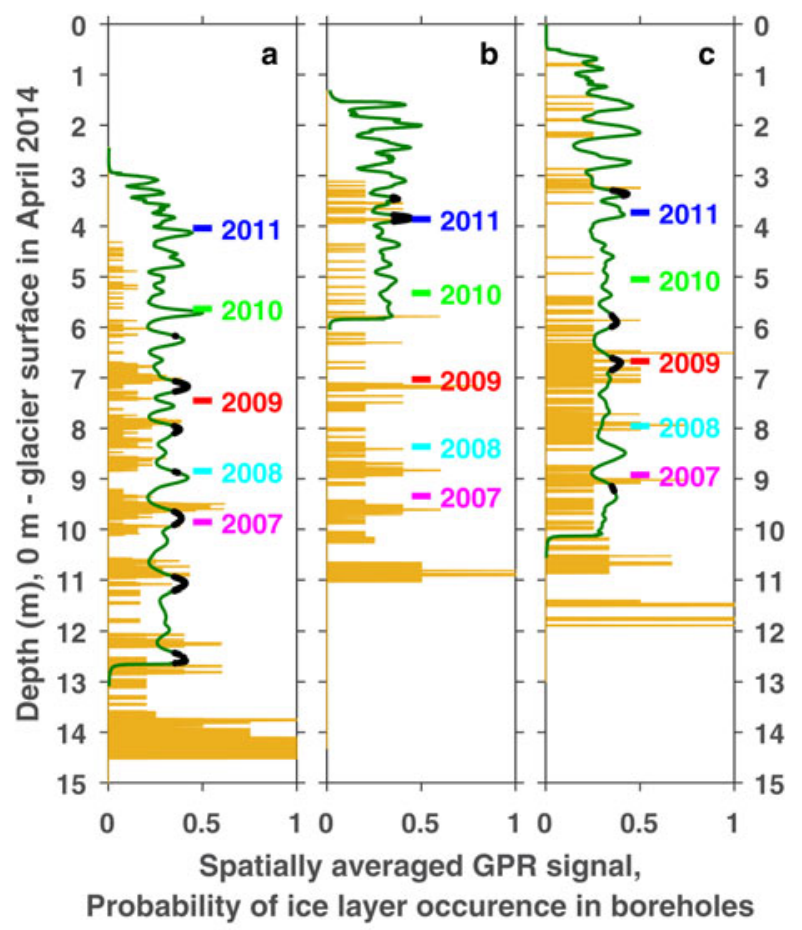

Probability of ice layer occurence from video surveys Averaged instantaneous amplitude of the GPR signal Samples in GPR data exceeding 0.7 of the amplitude range and within $0.15 \mathrm{~m}$ from the depths with ice layers observed in at least 2 boreholes

Fig. 7. Spatially averaged signals from the video and GPR data collected in 2012 (a), 2013 (b) and 2014 (c). Also shown are the summer surfaces 2011-2007 (coloured labels) interpreted from a $500 \mathrm{MHz}$ GPR profile Pelt2014 and corrected for surface accumulation and gravitational firn compaction after April 2012.

individual profiles. The ratios between the mean vertical and horizontal gradients in the averaged radar profiles (20122014) are 21.2, 37.2 and 23.3, while the corresponding values averaged over all individual profiles collected in each field campaign are 1.7, 3.4 and 1.8. Thus in the averaged radargrams vertical gradients are more dominant than in the radargrams of individual profiles.

The fraction of reflecting samples $(5 \%)$ resulting from the thresholding routine roughly corresponds to the relative ice content in firn found in cores and videos. However, compared with the ice layers visually observed in cores, reflectors in radar traces composed only $16-24 \%$ in number (Table 2 ). The reflector stratigraphy derived from the GPR traces measured in April 2012 in the closest vicinity of the boreholes 2, 5 and 8, surveyed by camera, is presented in Figure 6. In several cases strong reflectors are found within $0.15 \mathrm{~m}$ from the ice layers in the boreholes: 2.8, 4.5, 5.5, $7.2 \mathrm{~m}$ in borehole 2 (Figs 6a, b); 4.8 and $9.7 \mathrm{~m}$ in borehole 5 (Figs 6d, e); 3.9, 4.9 and $5.5 \mathrm{~m}$ in borehole 8 (Figs 6f, g). In some cases amplitude peaks of the GPR signal match with the ice layers found in boreholes (7.2-7.7 $\mathrm{m}$ in borehole 8 ), while the thresholding routine barely detects the reflections. However, the overall similarity between the two data sources is poor: radar reflectors are often detected where no ice layers were observed and most ice layers are not associated with radar reflectors sounded in vicinity of the corresponding boreholes.

The comparison between horizontally averaged radar and video data is presented in Figure 7. The GPR datasets collected 

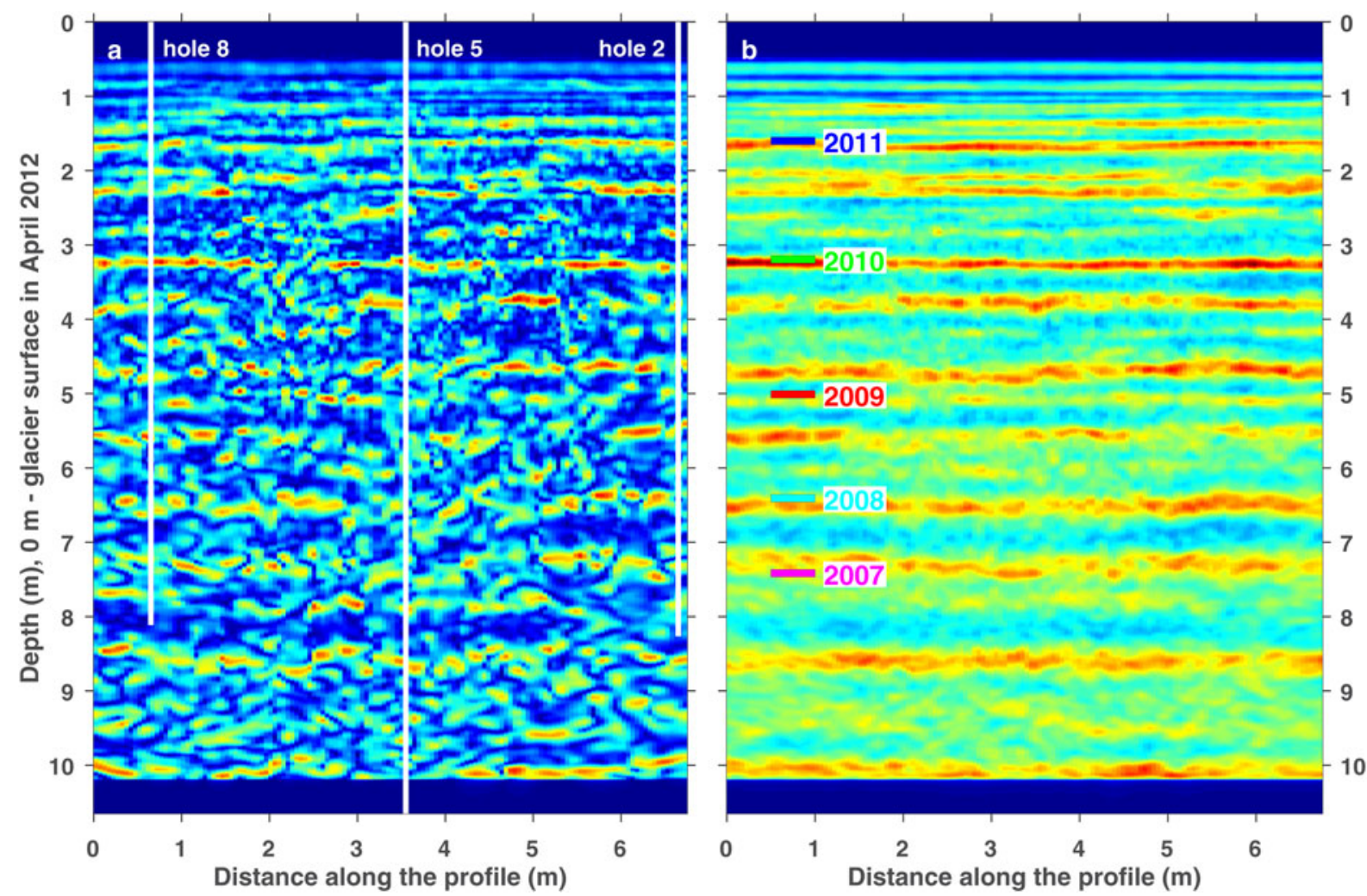

Fig. 8. Instantaneous amplitudes of the GPR data collected in April 2012. (a) radar profile crossing locations of boreholes 2, 5 and 8 (shown white, see Fig. 1b); (b) GPR data averaged in across-profile direction, also shown are the summer surfaces 2011-2007 (coloured labels) interpreted from a $500 \mathrm{MHz}$ GPR profile Pelt2014.

in 2012 and 2014 are more useful for the purpose than the 2013 data with the penetration depth of only $4.7 \mathrm{~m}$. The GPR signal (green curves) exhibits multiple spikes, which are expectedly consistent with the bright horizontally elongated areas in the averaged radargrams (Figs $7 \mathrm{a}$ and $8 \mathrm{~b}$ ). Black points show the samples in the averaged GPR traces that lie above 0.7 of the amplitude range of each of the data series and at the same time are within $0.15 \mathrm{~m}$ of the depth intervals where ice layers were observed in several (three for 2012 and two for 2013 and 2014 data) boreholes using the video surveys. The radar signal from all 3 years contains multiple spikes in the upper part of the profile, which can not be correlated with any maxima in the data from boreholes. However, in 2012 (Fig. 7a) when the largest number of boreholes was inspected using video and the radar survey reached below $10 \mathrm{~m}$ such samples are found at six depth intervals. In 2013 the overlap between the two series is limited to the upper $4.7 \mathrm{~m}$ and only five boreholes were inspected. The resulting apparent similarity between the radar and video signals is lower (Fig. 7b): only one of the two prominent maxima in video data is repeated by the GPR at $\approx 3.8 \mathrm{~m}$. In 2014 (Fig. 7c) all but one maxima found in the video data within overlapping depth range are repeated by the averaged GPR signal. Thus the averaged signals from the radar and video surveys show a prominent match in contrast with the data for individual traces and boreholes.

\section{DISCUSSION}

\subsection{Firn temperature and density}

Our results show that by the end of the ablation season in 2012 and 2013 the upper $10 \mathrm{~m}$ of the firn pack were isothermal at $0^{\circ} \mathrm{C}$. Similar measurements done on the 16 August 1965 at $1050 \mathrm{~m}$ a.s.l. (Zinger and others, 1966) and on the 1 August 1976 at $1120 \mathrm{~m}$ a.s.l. (Zagorodnov and Zotikov, 1980) yielded significantly lower firn temperature at $10 \mathrm{~m}$ depth of -3 and $2{ }^{\circ} \mathrm{C}$ correspondingly. During the last decades the upper accumulation area of Lomonosovfonna has likely seen transformation from the 'cold infiltration' zone to the 'warm infiltration' zone according to the classification of Shumskii (1964) and deep firn water storage and runoff from the domain are now possible.

In 2013 the first refreezing-induced warming in firn was registered as early as the first week of June and the firn profile was isothermal at $0^{\circ} \mathrm{C} 1$ month earlier than in 2012 (Fig. 3). This observation may be explained by the change of the wind direction over Svalbard in summer 2013 from the dominant north-westerly to an unusual south-south-westerly, which caused high air temperature (Lang and others, 2015).

The gradual increase of firn density measured in cores from $400-450 \mathrm{~kg} \mathrm{~m}^{-3}$ at the surface to $600 \mathrm{~kg} \mathrm{~m}^{-3}$ at the depth of $10 \mathrm{~m}$ is in correspondence with the previously reported results from the site (Pohjola and others, 2002; Vega and others, 2016). The prominent density increase of $\approx 130 \mathrm{~kg} \mathrm{~m}^{-3}$ measured between 1.5 and $5.3 \mathrm{~m}$ during April 2013-April 2014 is a result of several processes. Gravitational densification can account for $41 \mathrm{~kg} \mathrm{~m}^{-3} \mathrm{a}^{-1}$, when calculated following the method suggested by Ligtenberg and others (2011) using the density measured in 2013 core, temperature evolution measured during April 2014-April 2015 and assuming the annual accumulation rate of $0.75 \mathrm{~m} \mathrm{a}^{-1}$ (Van Pelt and others, 2014). The amount of meltwater refreezing in spring 2013 can be estimated from the firn refreezing capacity $c$ (Reijmer and others, 2012): $C=\rho|T| C L^{-1}$. Assuming that the mean temperature 
$(T)$ and density $(\rho)$ of firn at the depth $1.5-5.3 \mathrm{~m}$ are $-9^{\circ} \mathrm{C}$ and $440 \mathrm{~kg} \mathrm{~m}^{-3}$, correspondingly (see Figs 3 and 4), relative heat capacity of ice $(C)$ is $2050 \mathrm{~J} \mathrm{~kg}^{-1} \mathrm{~K}^{-1}$, latent heat of water fusion $(L)$ is $334000 \mathrm{~J} \mathrm{~kg}^{-1}$ the calculation yields a value of $24 \mathrm{~kg} \mathrm{~m}^{-3}$. Autumn refreezing of the meltwater suspended in pores of firn with the density of $500 \mathrm{~kg} \mathrm{~m}^{-3}$ could account for further densification by $25 \mathrm{~kg} \mathrm{~m}^{-3}$, assuming the liquid water content of $5 \%$ (Schneider and Jansson, 2004). Apart from the uncertainty in the above estimates, the resulting inconsistency of $40 \mathrm{~kg} \mathrm{~m}^{-3}$ between the observed density increase and the sum of possible contributions from different densification processes can be explained as an effect of multiple melt-freeze cycles in spring and summer 2013 and/or lateral variability of firn density.

\subsection{Firn stratigraphy}

Our observations show a high spatial heterogeneity in firn stratigraphy at the scale of several metres (Figs 5 and 8, Table 2). In accordance with earlier studies (e.g. Marsh and Woo, 1984), we interpret the observation as evidence of the highly heterogeneous nature of water infiltration and refreezing in snow and firn. The latter introduces uncertainty in point observations of firn properties and in results of simulations relying on the hypothesis of a horizontally uniform wetting front in firn (e.g. Gascon and others, 2014).

Spatial averaging of the video signal from multiple boreholes revealed that ice layers tend to group in several preferential horizons (Fig. 7). This finding partly deviates from the conclusions made by Brown and others (2011) for a thick firn pack with few thin ice lenses studied on the western slope of the Greenland ice sheet (1997 m a.s.I.). In contrast to our results Brown and others (2011) did not find any horizontally consistent pattern in firn stratigraphy across their eight cores spaced by 1.5-14 m. Although, similar to our findings, their $500 \mathrm{MHz}$ GPR survey on a $20 \mathrm{~m} \times 20 \mathrm{~m}$ grid returned several laterally consistent internal reflection horizons (IRHs), which were interpreted as annual features formed by preferential formation of ice layers at the summer surfaces from previous years. Dunse and others (2008) presented a similar interpretation of horizontally coherent IRHs found in firn at the Greenland ice sheet at a slightly lower site (1940 m a.s.l.).

To test if the maxima in our grid-averaged GPR and also video data likewise originate at the buried summer surfaces, we compare their depths with positions of the summer surfaces 2011-2007 detected by Van Pelt and others (2014) in a $15 \mathrm{~km}$ long $500 \mathrm{MHz}$ GPR profile done at Lomonosovfonna and Nordenskiöldbreen in April 2012. The uppermost point of this profile was within $10 \mathrm{~m}$ from our plot and is used here for comparison. The summer surfaces are interpreted from IRHs based on their distinct character and lateral continuity at the kilometre scale. To estimate the depths of the summer surfaces after April 2012 we introduce offsets accounting for the gravitational densification of firn following the aforementioned routine (Ligtenberg and others, 2011). Offsets calculated for April 2013 and 2014 vary from 0.13 to $0.53 \mathrm{~m} \mathrm{a}^{-1}$ for different depth levels.

In 2012 the summer surfaces found by Van Pelt and others (2014) (coloured labels at 4.0, 5.6, 7.5, 8.9 and $9.9 \mathrm{~m}$ in Fig. 7a, also see Fig. 8b) closely match with the maxima in our grid-averaged GPR and video data (green and yellow series in Fig. 7a). Positions of some of the summer surfaces in the following 2 years are also in reasonable correspondence with the maxima in the video and GPR data $(7.1,8.5,9.4 \mathrm{~m}$ in 2013, see Fig. 7b; 3.8, 6.8, 8.1, 9.1 $\mathrm{m}$ in 2014, see Fig. 7c), suggesting that the horizons of preferential ice layer formation are persistent in time. The apparent biases can be attributed to the local scale variability in the accumulation rate, effects of firn metamorphism or the inaccuracies in the vertical scales of GPR and video data and the estimated compression rates.

In line with earlier studies (Dunse and others, 2008; Brown and others, 2011; Van Pelt and others, 2014; Sold and others, 2015) we suggest that most of the prominent maxima in the composite data from our radar and video surveys originate at the firn horizons exposed to melt at the end of ablation seasons (summer surfaces). The rate and pattern of water infiltration through snow and firn is highly dependent on the structure of the media (Campbell and others, 2006). The upper decimetres of snow continuously exposed to melt (often referred to as 'summer surface') are likely to have an increased density as a result of multiple melt-freeze cycles caused by fluctuations of the surface energy flux around zero at the daily to weekly scale (Dunse and others, 2008). Therefore, it can be expected that formation of ice layers and IRHs associated with them will occur at the buried summer surfaces with pre-existing firn layers that are less permeable to the flow of water.

Some maxima in our data $(4.7,6.2,7.2$ and $8 \mathrm{~m}$ in Fig. 7a) fall between the summer surfaces from Van Pelt and others (2014). They are also noticeable on the $500 \mathrm{MHz}$ radargrams (Van Pelt and others, 2014) but were not regarded as buried summer surfaces based on the lack of lateral consistency on the kilometre scale. The IRHs falling in between the depths interpreted as buried summer surfaces also appear as less horizontally consistent features in our $800 \mathrm{MHz}$ radargram (Fig. 8b). We interpret them as firn layers that experienced additional densification due to liquid water refreezing events during the accumulation season or were excessively packed by wind (Bøggild, 2000; Parry and others, 2007) before being covered by successive accumulation. Surface melt rates during occasional inter-seasonal melt events are likely to be lower than during the ablation season, causing less prominent perturbations in snow stratigraphy resulting in less laterally consistent IRH. The snow surfaces exposed to strong winds often have a rough topography and the IRHs associated with such buried layers can be expected to be undulating and horizontally intermittent.

\subsection{Assessing the methods used to map firn stratigraphy}

Direct observation in firn cores and video surveys in multiple boreholes yielded similar values of relative ice content in firn of $\approx 8 \%$. At the same time video inspections resulted in significantly larger mean thickness and smaller number of ice layers than core observations, suggesting that thin ice layers were omitted by video records or post processing. At the expense of reduced data quality the video surveys offer two main advantages over more conventional ocular observations of firn cores. Firstly, drilling of the narrow boreholes by auger is faster than coring and, secondly, there is no need for transporting the cores to the cold laboratory or arranging the facilities for core analysis in the field. It is suggested that the reproducibility of the coring results can be improved by thorough cleaning of the borehole walls before filming and 
using video acquisition hardware allowing for faster sampling and possibly manual control on the camera sensitivity.

The point nature and vertical orientation of studies in boreholes bears the risk of over-interpreting recovered ice layers as laterally continuous. However, the observed high spatial variability of firn structure (Table 2) and the poor match between stratigraphy profiles from boreholes separated by $3-18 \mathrm{~m}$ and surveyed in one field campaign (Fig. 5) limits the value of stratigraphy studies at single points and calls for spatial averaging over several cores or borehole video surveys to reveal the depth intervals where preferential ice layer formation is observed.

While evidences from studies in boreholes suggest that ice layers tend to be thicker and more laterally consistent with depth (Figs 4a-c, 5 and 7), the regions with increased backscatter of the GPR signal become less distinctive with depth (Figs 6b, e, g, 7 and 8): the vertical gradients in the instantaneous amplitude are less steep and reflectors are less consistent. These observations are expected from the applied $800 \mathrm{MHz}$ GPR system that allow to sounding firn down to $\sim 10.6 \mathrm{~m}$. Due to the gravitational settling and water refreezing in the firn matrix the density gradients between ice layers and adjacent firn decrease with depth and associated differences in electric permittivity are also less pronounced.

Small lateral extent of stratigraphical features in firn, does not justify studies in boreholes for characterization of their shape and size due to associated limitations in horizontal resolution of such surveys. GPR studies can be done with a very high horizontal resolution and combined with effective techniques for post-processing and quantitative analysis, which potentially allows for detailed mapping of the firn structure. At the same time the interpretation of the individual radar reflectors is not straightforward and firn cores and/or video inspections in boreholes remain of great importance for validation of the GPR results and constraining the velocity model used in data post-processing and for conversion of the vertical scale to distance units.

The match observed between the reflectors identified in GPR data and ice layers found in individual boreholes is poor (Fig. 6). However, considering the good match between grid-averaged video and GPR data (Fig. 7), we suggest that radar returns are associated with ice layers in firn but may also come from other targets often related to them. High amplitude of the GPR signal returns is caused by spatial discontinuities of the firn dielectric permittivity and electrical conductivity (Hubbard and Glasser, 2005). In the cold firn the latter can be caused not only by sharp density contrasts (firn/ice), which can be seen in both core and video surveys, but also by less prominent changes in firn density, alternations of firn micro structure and conductive inclusions (Arcone, 2009; Sold and others, 2015), detection of which in boreholes would require more detailed studies. The mismatch between visual and radar derived descriptions of firn stratigraphy (Fig. 7) can also be attributed to the uncertainties arising from the lateral variability in firn density not captured by a single firn core. Measured firn density is used in the migration routine and in the time/ depth conversion of the vertical scale.

The suggested thresholding routine produces distinct and discrete radar reflectors, which should not be over-interpreted due to several limitations. Firstly the routine is most sensible to the amplitude of the GPR signal, consequently targets with strong contrasts in relative permittivity or electric conductivity with respect to the over- and underlying layers will result in pronounced reflectors independent of the reflecting object's actual thickness. Secondly, a reflection generated by a target in firn is a single wavelet that in our case has the length $\lambda=0.25 \mathrm{~m}$. Thus even very thin targets in firn may appear as relatively wide reflectors in radargrams and the derived reflectors can overestimate the presence of reflecting objects.

\section{CONCLUSIONS}

The temporal and spatial dynamics in stratigraphy and density of firn at Lomonosovfonna (1200 m a.s.I.), Svalbard, were studied in April 2012-14 on plots $(\approx 10 \mathrm{~m} \times 10 \mathrm{~m} \times 10 \mathrm{~m})$ using cores, videos surveys in multiple boreholes and 800 $\mathrm{MHz}$ GPR profiling. We present results of the field studies and report on the strengths, weaknesses and agreement of the three methods used for stratigraphical descriptions.

Results from three cores and video surveys in multiple boreholes suggest that the upper $12 \mathrm{~m}$ of firn contain multiple ice layers $0.1-50 \mathrm{~cm}$ thick constituting $\approx 8 \%$ of the profile. Most ice layers are rather thin $(\approx 2 \mathrm{~cm})$ and are laterally discontinuous at the scales $>3 \mathrm{~m}$. Ice layers in firn tend to be concentrated in several preferential horizons, which are also consistent with the maxima in the grid-averaged instantaneous amplitude of the GPR signal. We interpret the horizons as buried surfaces that have been previously exposed to melt or wind-driven densification, several of them were consistently recovered in the three field campaigns.

While direct firn observations in cores provided most details about firn stratigraphy, video surveys in boreholes omitted thin layers and allowed to distinguish only between firn and ice. The poor agreement between ice layers visually observed in individual boreholes and reflections found in individual GPR traces is attributed to differences in the physical principles behind the methods and imperfections of the data acquisition routines. The tight correlation between grid-averaged video and GPR data suggests that reflections are associated with the ice layers in firn and that the GPR surveys can be utilized to recover depth intervals with preferential ice layer formation.

The high lateral variability of the firn strata, calls for observations in multiple cores or boreholes to derive more reliable density profiles and distinguish layers with increased probability of ice layer occurrence. Limited lateral extent of ice volumes in firn calls for utilization of high resolution GPR studies for characterization of their shape and size. Such detailed stratigraphic maps along with borehole studies for validation can provide an insight into the processes of water flow and refreezing in firn.

\section{ACKNOWLEDGEMENTS}

This publication is contribution N82 of the Nordic Centre of Excellence SVALI, 'Stability and Variations of Arctic Land Ice', funded by the Nordic Top-level Research Initiative. This work is also funded by the Vetenskapsrådet grant 621-20143735 (V. A. Pohjola). Logistical support was provided by the Swedish Polar Research Secretariat, the Norwegian Polar Institute and the University Centre in Svalbard. The authors are grateful to the Ymer-80 foundation, Arctic Field Grant of the Research Council of Norway, Margit Althins stipend of the Royal Swedish Academy of Sciences for additional funding of the field campaigns. We are also indebted to the 
two Reviewers who contributed their time and effort to the constructive comments that helped to improve the manuscript.

\section{REFERENCES}

Albert M, Koh G and Perron F (1999) Radar investigations of melt pathways in a natural snowpack. Hydrol. Process., 13(18), 2991-3000, (doi: 10.1002/(SICI)1099-1085(19991230)13: $18<2991:: A I D-H Y P 10>3.0 . C O ; 2-5)$

Arcone SA (2009) Glaciers and Ice Sheets. In Jol HM ed. Ground penetrating radar theory and applications, chapter 12, Elsevier, Amsterdam, 361-392, (doi: 10.1016/B978-0-444-533487.00012-0)

Bartelt P and Lehning M (2002) A physical SNOWPACK model for the Swiss avalanche warning: part I: numerical model. Cold Reg. Sci. Technol., 35(3), 123-145, (doi: 10.1016/S0165-232X (02)00074-5)

Bell C and 7 others (2008) Spatial and temporal variability in the snowpack of a High Arctic ice cap: implications for masschange measurements. Ann. Glaciol., 48(1), 159-170 (doi: 10.3189/172756408784700725)

Benson CS (1960) Stratigraphic studies in the snow and firn of the Greenland ice sheet. (Dissertation. PhD thesis, California Institute of Technology)

Bøggild CE (2000) Preferential flow and melt water retention in cold snow packs in West-Greenland. Nord. Hydrol., 31(4-5), 287 300, ISSN 0029-1277

Brown J, Harper J, Pfeffer WT, Humphrey N and Bradford J (2011) High-resolution study of layering within the percolation and soaked facies of the Greenland ice sheet. Ann. Glaciol., 52(59), 35-42 (doi: 10.3189/172756411799096286)

Campbell FMA, Nienow PW and Purves RS (2006) Role of the supraglacial snowpack in mediating meltwater delivery to the glacier system as inferred from dye tracer investigations. Hydrol. Process., 20(4), 969-985, (doi: 10.1002/hyp.6115)

Christianson K, Kohler J, Alley RB, Nuth C and van Pelt WJJ (2015) Dynamic perennial firn aquifer on an Arctic glacier. Geophys. Res. Lett., 42(5), 1418-1426, (doi: 10.1002/2014GL062806), 2014GL062806)

Cogley J and 10 others (2011) Glossary of glacier mass balance and related terms. IHP-VII Technical Documents in Hydrology No. 86, IACS Contribution No. 2, UNESCO-IHP, Paris (doi: 10.1017/S0032247411000805)

Colbeck SC (1982) An overview of seasonal snow metamorphism. Rev. Geophys., 20(1), 45-61, (doi: 10.1029/RG020i001p00045)

Dunse T and 5 others (2008) Characteristics and small-scale variability of GPR signals and their relation to snow accumulation in Greenland's percolation zone. J. Glaciol., 54(185), 333-342 (doi: 10.3189/002214308784886207)

Evangelidis G and Psarakis E (2008) Parametric image alignment using enhanced correlation coefficient maximization. IEEE Trans. Pattern Anal. Mach. Intell., 30(10), 1858-1865, (doi: 10.1109/TPAMI.2008.113)

Fierz C and 8 others (2009) The international classification for seasonal snow on the ground. IHP-VII Technical Documents in Hydrology, No 83, IACS contribution No 1. UNESCO-IHP, Paris

Forster RR, Davis CH, Rand TW and Moore RK (1991) Snowstratification investigation on an Antarctic ice stream with an X-band radar system. J. Glaciol., 37(127), 323-325

Forster RR and 12 others (2014) Extensive liquid meltwater storage in firn within the Greenland ice sheet. Nat. Geosci., 7(2), 95-98, (doi: 10.1038/ngeo2043)

Gascon G, Sharp M, Burgess D, Bezeau P and Bush ABG (2013) Changes in accumulation-area firn stratigraphy and meltwater flow during a period of climate warming: Devon Ice Cap, Nunavut, Canada. J. Geophys. Res.: Earth Surf., 118(4), 23802391, (doi: 10.1002/2013JF002838), 2013JF002838

Gascon G and 6 others (2014) How well is firn densification represented by a physically based multilayer model? Mode evaluation for Devon Ice Cap, Nunavut, Canada. J. Glaciol., 60 (222), 694-704 (doi: 10.3189/2014JoG13J209)

Gray SH (1992) Frequency-selective design of the Kirchhoff migration operator. Geophys. Prospect., 40(5), 565-571, (doi: 10.1111/j.1365-2478.1992.tb00541.x)

Hagedoorn JG (1954) A process of seismic reflection interpretation. Geophys. Prospect., 2(2), 85-127, (doi: 10.1111/j.13652478.1954.tb01281.x)

Harper J, Humphrey N, Pfeffer WT, Brown J and Fettweis X (2012) Greenland ice-sheet contribution to sea-level rise buffered by meltwater storage in firn. Nature, 491(7423), 240-243, (doi: 10.1038/nature11566), 10.1038/nature11566

Hawley RL and Waddington ED (2011) In situ measurements of firn compaction profiles using borehole optical stratigraphy. J. Glaciol., 57(202), 289-294, (doi: 10.3189/002214311796405889)

Hubbard B and Glasser NF (2005) Field techniques in glaciology and glacial geomorphology, chapter Ice radar. Wiley, Chichester, 148-178

Hubbard B, Roberson S, Samyn D and Merton-Lyn D (2008) Digital optical televiewing of ice boreholes. J. Glaciol., 54(188), 823830 (doi: 10.3189/002214308787779988)

Illangasekare TH, Walter RJ, Meier MF and Pfeffer WT (1990) Modeling of meltwater infiltration in subfreezing snow. Water Resour. Res., 26 (5), 1001-1012, (doi: 10.1029/WR026i005p01001)

Isaksson $\mathrm{E}$ and 14 others (2001) A new ice-core record from Lomonosovfonna, Svalbard: viewing the 1920-97 data in relation to present climate and environmental conditions. J. Glaciol., 47(157), 335-345, (doi: 10.3189/172756501781832313)

Jordan R, Albert M and Brun E (2008) Snow and climate: physical processes, surface energy exchange and modeling, chapter Physical processes within the snow cover and their parameterization. Cambridge University Press, Cambridge, 12-69

Katsushima T, Kumakura T and Takeuchi Y (2009) A multiple snow layer model including a parameterization of vertical water channel process in snowpack. Cold Reg. Sci. Technol., 59, 143-151, (doi: 10.1016/j.coldregions.2009.09.002), International Snow Science Workshop (ISSW) 2008

Katsushima T, Yamaguchi S, Kumakura T and Sato A (2013) Experimental analysis of preferential flow in dry snowpack. Cold Reg. Sci. Technol., 85(0), 206-216, (doi: 10.1016/j. coldregions.2012.09.012)

Kovacs A, Gow AJ and Morey RM (1995) The in-situ dielectric constant of polar firn revisited. Cold Reg. Sci. Technol., 23(3), 245256, (doi: 10.1016/0165-232X(94)00016-Q)

Lang C, Fettweis X and Erpicum M (2015) Stable climate and surface mass balance in Svalbard over 1979-2013 despite the Arctic warming. Cryosphere, 9(1), 83-101 (doi: 10.5194/tc-9-83-2015)

Langhammer L (2014) Application and evaluation of a borehole camera system for mapping firn stratigraphy. (Master's thesis, Oslo University)

Langley K, Lacroix P, Hamran SE and Brandt O (2009) Sources of backscatter at $5.3 \mathrm{GHz}$ from a superimposed ice and firn area revealed by multi-frequency GPR and cores. J. Glaciol., 55 (190), 373-383 (doi: 10.3189/002214309788608660)

Leroux NR and Pomeroy JW (2016) A 2D model for simulating heterogeneous mass and energy fluxes through melting snowpacks. Cryosphere Discuss., 2016, 1-26 (doi: 10.5194/tc-2016-55)

Ligtenberg SRM, Helsen MM and van den Broeke MR (2011) An improved semi-empirical model for the densification of Antarctic firn. Cryosphere, 5(4), 809-819 (doi: 10.5194/tc-5-809-2011)

Machguth H, Eisen O, Paul F and Hoelzle M (2006) Strong spatial variability of snow accumulation observed with helicopterborne GPR on two adjacent Alpine glaciers. Geophys. Res. Lett., 33(13), (doi: 10.1029/2006GL026576), I13503

Machguth $\mathrm{H}$ and 9 others (2016) Greenland meltwater storage in firn limited by near-surface ice formation. Nat. Clim. Change 6, 390393 (doi: 10.1038/nclimate2899)

Malone T, Hubbard B, Merton-Lyn D, Worthington P and Zwiggelaar R (2013) Borehole and Ice Feature Annotation Tool (BIFAT): a program for the automatic and manual annotation of 
glacier borehole images. Comput. Geosci., 51(0), 381-389, (doi: 10.1016/j.cageo.2012.09.002)

Marsh P and Woo MK (1984) Wetting front advance and freezing of meltwater within a snow cover: 1 . observations in the Canadian Arctic. Water Resour. Res., 20(12), 1853-1864, (doi: 10.1029/ WR020i012p01853)

Marshall HP, Schneebeli M and Koh G (2007) Snow stratigraphy measurements with high-frequency FMCW radar: comparison with snow micro-penetrometer. Cold Reg. Sci. Technol., 47(1-2), 108-117, (doi: 10.1016/j.coldregions.2006. 08.008), a Selection of papers presented at the International Snow Science Workshop, Jackson Hole, Wyoming, September 19-24, 2004

Nordli Ø, Przybylak R, Ogilvie A and Isaksen K (2014) Long-term temperature trends and variability on Spitsbergen: the extended Svalbard Airport temperature series, 1898-2012. Polar Res., 33, (doi: 10.3402/polar.v33.21349)

Oppenheim AV, Schafer RW and Buck JR (1999) Discrete-time signal processing, 2nd edn. Prentice Hall, Upper Saddle River, NJ, 2 edition

Pälli A and 6 others (2002) Spatial and temporal variability of snow accumulation using ground-penetrating radar and ice cores on a Svalbard glacier. J. Glaciol., 48(162), 417-424 (doi: 10.3189/ 172756502781831205)

Parry V and 6 others (2007) Investigations of meltwater refreezing and density variations in the snowpack and firn within the percolation zone of the Greenland ice sheet. Ann. Glaciol., 46(1), 6168 (doi: 10.3189/172756407782871332)

Pohjola VA (1994) TV-video observations of englacial voids in Storglaciären, Sweden. J. Glaciol., 40(135), 231-240

Pohjola VA and 7 others (2002) Effect of periodic melting on geochemical and isotopic signals in an ice core from Lomonosovfonna, Svalbard. J. Geophys. Res.: Atmos., 107(D4), (doi: 10.1029/2000JD000149)

Proksch M, Löwe H and Schneebeli M (2015) Density, specific surface area, and correlation length of snow measured by high-resolution penetrometry. J. Geophys. Res.: Earth Surf., 120(2), 346-362, (doi: 10.1002/2014JF003266), 2014JF003266

Reijmer $\mathrm{CH}$ and Hock $\mathrm{R}$ (2008) Internal accumulation on Storglaciären, Sweden, in a multi-layer snow model coupled to a distributed energy- and mass-balance model. J. Glaciol., 54 (184), 61-72 (doi: 10.3189/002214308784409161)

Reijmer $\mathrm{CH}$, van den Broeke MR, Fettweis X, Ettema J and Stap LB (2012) Refreezing on the Greenland ice sheet: a comparison of parameterizations. Cryosphere, 6(4), 743-762 (doi: 10.5194/tc6-743-2012)

Richardson C, Aarholt E, Hamran SE, Holmlund P and Isaksson E (1997) Spatial distribution of snow in western Dronning Maud land, east Antarctica, mapped by a ground-based snow radar. J. Geophys. Res.: Solid Earth, 102(B9), 20343-20353, (doi: 10.1029/97JB01441)

Schneebeli M (1995) Development and stability of preferential flow paths in a layered snowpack. In Biogeochemistry of Seasonally Snow-Covered Catchments (Proceedings of a Boulder Symposium July 1995) IAHS Publ. no. 228, 228, IAHS, 89-95

Schneebeli M, Pielmeier C and Johnson JB (1999) Measuring snow microstructure and hardness using a high resolution penetrometer. Cold Reg. Sci. Technol., 30(1-3), 101-114, (doi: 10.1016/ S0165-232X(99)00030-0)

Schneider WA (1978) Integral formulation for migration in two and three dimensions. Geophysics, 43(1), 49-76 (doi: 10.1190/ 1.1440828)

Schneider T and Jansson P (2004) Internal accumulation in firn and its significance for the mass balance of Storglaciären Sweden. J. Glaciol., 50(168), 25-34 (doi: 10.3189/172756504781830277)

Schweizer J, Kronholm K, Jamieson JB and Birkeland KW (2008) Review of spatial variability of snowpack properties and its importance for avalanche formation. Cold Reg. Sci. Technol., 51, 253-272, (doi: 10.1016/j.coldregions.2007. 04.009), international Snow Science Workshop (ISSW) 2006

Shumskii PA (1964) Principles of structural glaciology, chapter Zones of ice formation. Dover Publications, Inc., New York

Sjögren B and 6 others (2007) Instruments and methods - determination of firn density in ice cores using image analysis. J. Glaciol., 53(182), 413-419, (doi: 10.3189/002214307783258369)

Sold L, Huss M, Eichler A, Schwikowski M and Hoelzle M (2015) Unlocking annual firn layer water equivalents from ground-penetrating radar data on an alpine glacier. Cryosphere, 9(3), 10751087 (doi: 10.5194/tc-9-1075-2015)

Sturm M and Benson C (2004) Scales of spatial heterogeneity for perennial and seasonal snow layers. Ann. Glaciol., 38(1), 253-260 (doi: 10.3189/172756404781815112)

Sugiyama S and 6 others (2012) Snow density along the route traversed by the Japanese-Swedish Antarctic Expedition 2007/08. J. Glaciol., 58(209), 529-539 (doi: 10.3189/2012Jo G11J201)

Tape KD, Rutter N, Marshall HP, Essery R and Sturm M (2010) Recording microscale variations in snowpack layering using near-infrared photography. J. Glaciol., 56(195), 75-80 (doi: 10.3189/002214310791190938)

Trujillo E and Lehning M (2015) Theoretical analysis of errors when estimating snow distribution through point measurements. Cryosphere, 9(3), 1249-1264 (doi: 10.5194/tc-9-1249-2015)

Van de Wal RSW and 6 others (2002) Reconstruction of the historical temperature trend from measurements in a medium-length borehole on the Lomonosovfonna plateau, Svalbard. Ann. Glaciol., 35, 371-378, (doi: 10.3189/172756402781816979)

Van Pelt WJJ and 5 others (2012) Simulating melt, runoff and refreezing on Nordenskiöldbreen, Svalbard, using a coupled snow and energy balance model. Cryosphere, 6(3), 641-659 (doi: 10.5194/ tc-6-641-2012)

Van Pelt WJ and 5 others (2014) Inverse estimation of snow accumulation along a radar transect on Nordenskiöldbreen, Svalbard. J. Geophys. Res.: Earth Surf., 119(4), 816-835, (doi: 10.1002/ 2013JF003040)

Vaughan D and 13 others (2013) Observations: Cryosphere, book section 4, 317-382. Cambridge University Press, Cambridge, United Kingdom and New York, NY, USA, (doi: 10.1017/ CBO9781107415324.012)

Vega CP and 8 others (2015) First ice core records of $\mathrm{NO}^{3}-$ stable isotopes from Lomonosovfonna, Svalbard. J. Geophys. Res.: Atmos., 120(1), 313-330, (doi: 10.1002/2013JD020930), 2013JD020930

Vega CP and 9 others (2016) A synthetic ice core approach to estimate ion relocation in an ice field site experiencing periodical melt: a case study on Lomonosovfonna, Svalbard. Cryosphere, 10(3), 961-976 (doi: 10.5194/tc-10-961-2016)

Waldner PA, Schneebeli M, Schultze-Zimmermann $U$ and Flühler $\mathrm{H}$ (2004) Effect of snow structure on water flow and solute transport. Hydrol. Process., 18(7), 1271-1290, (doi: 10.1002/hyp.1401)

Wendl IA (2014) High resolution records of black carbon and other aerosol constituents from the Lomonosovfonna 2009 ice core. ( $\mathrm{PhD}$ thesis, Departement für Chemie und Biochemie der Universität Bern)

Yelf R (2004) Where is true time zero? In Proceedings of the Tenth International Conference on Ground Penetrating Radar, 2004, volume 1, 279-282

Zagorodnov VS and Zotikov IA (1980) Core drilling at Spitsbergen (in Russian). Materialy Glatsiologicheskih Issledovanii: khronika, obsujdeniya (Data of glaciological studies), 40, 157-163

Zinger YM and 5 others (1966) Study of glaciers at Spitsbergen by a Soviet expedition during summer 1965 (in Russian). Materialy Glatsiologicheskih Issledovanii: khronika, obsujdeniya (Data of glaciological studies), 12, 59-72 